\title{
Investigation of groundwater potential using integrated geophysical methods in Moloko-Asipa, Ogun State, Nigeria
}

\author{
A. A. Alabi ${ }^{1}$ - S. A. Ganiyu' ${ }^{1}$ O. A. Idowu² A. F. Ogabi ${ }^{1}$ - O. I. Popoola ${ }^{3}$
}

Received: 23 October 2019 / Accepted: 26 February 2021 / Published online: 8 April 2021

(c) The Author(s) 2021

\begin{abstract}
Water is essential for livelihood, development, and industrial growth. Its exploration in sufficient quantity is required where it does not freely occur on the surface. This research was aimed to delineate aquifer regions and provide information on the subsurface lithology of Moloko-Asipa Southwestern Nigeria. A combination of eight traverses investigated with very low frequency electromagnetic (VLF-EM) method at $5 \mathrm{~m}$ constant sampling interval and ten vertical electrical sounding (VES) were carried out in the survey. Measurements from the VLF-EM survey were processed with Karous and Hjelt filtering to give the resistivity contrast across the selected profiles. The VES data processing involved an automatic approximation of the initial resistivity and thickness of the geoelectric layers with IPI2Win and further filtering by WinResist iteration. Estimation of Dar-Zarrouk parameters was also employed to investigate the aquifer protective capacity of the area. The processed VLFEM results showed the geology of the area to an average depth of $25 \mathrm{~m}$. The geoelectric section of the VES data revealed minimum of 3 layers from sandy top soil to weathered layer and fresh basement with an average resistivity values of 1,816 , 926 and 17,503 $\Omega \mathrm{m}$, respectively. The integration of VLF-EM and VES in the investigation revealed that the potential for groundwater exploration in the study area is poor due to the thin nature of the weathered layer and its shallow depth to basement. The aquifer protective capacity of the area was likewise inferred to be poor.
\end{abstract}

Keywords Integrated $\cdot$ Groundwater $\cdot$ VLF-EM $\cdot$ Resistivity $\cdot$ Dar-Zarrouk

\section{Introduction}

The study of groundwater exploration is increasing in recent times due to its inevitable needs for livelihood, development and industrial growth. Groundwater plays a vital role as it is a dependable primary source of freshwater for all needs in areas where surface water is inadequate or not available (WWDR 2015). Though groundwater exploration in some areas like hard rock terrain is very challenging and sometimes tricky as its potential depends mainly on the thickness of the weathered or fractured layer overlying the basement,

A. A. Alabi

derylab@yahoo.com

1 Department of Physics, Federal University of Agriculture, Abeokuta, Ogun State, Nigeria

2 Department of Water Resources Management and Agricultural Meteorology, Federal University of Agriculture, Abeokuta, Ogun State, Nigeria

3 Department of Physics, University of Ibadan, Ibadan Oyo State, Nigeria a thorough hydrogeological investigation dwindles these challenges (Al-Garni 2009). New developments have been carried out to characterize the nature and the pattern of flow of subsurface water which generally categorized groundwater into groundwater found in the unsaturated zone and groundwater located in the saturated site (Delleur 2006). This categorization is due to the differences in the physics of water flow in saturated and unsaturated zones. In the study of groundwater potential, the knowledge of the geology of the area under investigation is very crucial as the understanding of the geology of the site helps to delineate possible saturated zones from unsaturated zones beneath the crust (Nimmo 2005; Hassan et al. 2017). Apart from having a good knowledge of the geology of the study area, correct interpretations of hydraulic test's result and perfect interpretations of resulting predictions are needed to have a successful groundwater exploration (Badmus and Olatinsu 2012; Akintayo et al. 2014; Lukuman et al. 2015). The application of different principles of physics and earth science is generally related to providing a good understanding of the subsurface structure, which are very important for both scientific 
and economic reasons (Kamil 2008). The field source that is required to generate information about an object of interest in the subsurface can either be artificial or natural (Henderson 1992). The observed natural fields can originate from a combination of sources in the environment of the target that is being investigated. Hence a filtering process is needed to eliminate the field signals from all other sources to get the specific signal that will indeed characterize the target (Janvier et al. 2015). One advantage of natural field source is that it does not require any additional deployment to generate the field, unlike the artificial source where a further deployment is needed. However, the artificial fields have an advantage such that the source parameters can be predetermined and can be used to eliminate noise from the obtained signal (James 2009; Ram and Rao 2018; Odipe et al. 2018; Nuraddeen et al. 2019). This study was aimed to delineate the regions of aquifer and provide information on the geology of the study area. With the view of characterizing the subsurface lithology, identifying structures that would reveal information on the potential for groundwater exploration in the area is also a goal.

Olayanju (2011) combined very low frequency electromagnetic (VLF-EM) with offset Wenner resistivity methods of geophysical survey to evaluate the groundwater spring source in Akure, Southwestern Nigeria. It was concluded that the adoption of an integrated method of hydrogeological survey provides a better result for a successful groundwater exploration process. A geophysical investigation for groundwater development involving the electrical resistivity and electromagnetic VLF methods was likewise carried out by Afolayan et al. (2004) in the premises of Obafemi Awolowo University, Ile-Ife, southwestern Nigeria. Three VLF-EM profiling were carried out and used as a reconnaissance survey to locate the conductive zones where six vertical electrical soundings were done. The VLF normal and filtered real component anomalies from the survey revealed five major geological interfaces while the geoelectric section prepared from VES interpretation delineates four subsurface layers. The researchers used a lithological log from a test borehole at one of the VES stations to corroborate the predicted sequence and its structural disposition of the subsurface by the VLF-EM and VES investigation. Falade et al. (2019) integrated very low frequency electromagnetic (VLF-EM) with vertical electrical sounding (VES) electrical resistivity methods to determine groundwater prospect in Ilara-Mokin, Akure, Nigeria. The VLF-EM profiling was carried out on eight traverses and the results revealed the points which are relatively conductive with depth. Eighteen VES stations with maximum electrode separation of $65 \mathrm{~m}$ along the six traverses trending East-West were then positioned based on the results of the VLF-EM survey. The researchers concluded that the integration of VLF-EM and VES aids groundwater development and recommend that borehole logging can be adapted to characterize the aquifer for better integration results. The integration of VLF-EM and VES geophysical methods for groundwater exploration in hard rock areas was also studied by Adelusi et al. (2014). The problems associated with VES in hard rock terrains with surface or near-surface expression of outcrops were identified. The researchers submitted that the use of VLF-EM becomes imperative in mapping the basement structures relevant to groundwater development in such areas. The VLF-EM method yields a higher depth of penetration in hard rock areas because of their high resistivity (McNeill and Labson 1991). One of the advantages of integrating VLF-EM with VES is that its collection of data is relatively fast and inexpensive compared to many other geophysical methods (Olafisoye et al. 2012). VLF-EM on its own is very effective in locating zones of high electrical conductivity, though all electrical conductivity affects it, and it needs to be filtered during interpretation (Yusuf 2016). VLF-EM method has probably been the most popular tool for quick mapping of near-surface geologic structures in mineral exploration. It is, however, increasingly used for shallow groundwater exploration as a reconnaissance tool for weathered layer investigations (Palacky et al. 1981). Also, VLF-EM has proved to be successful in identifying deep water-bearing fractures in bedrock (Sundararajan et al. 2007).

Vertical electrical soundings (VES) and geophysical logs were employed by Oladele and Odubote (2017) to map and characterize aquifer units in a typical complex transition zone of Ijebu Ode. The study area is a zone between the Precambrian Basement rocks and Cretaceous sediments of Dahomey Basin, Southwestern Nigeria (Osinowo and Olayinka 2012). Sixteen VES were acquired using Schlumberger array method with maximum current electrode separation of $900 \mathrm{~m}$. The interpretation of the VES data revealed four geoelectric layers with the weathered layer at $80 \mathrm{~m}$ depth in the subsurface. The researchers concluded that the study area has a low potential for groundwater exploration. Badmus and Olatinsu (2010) likewise carried out aquifer characterization and groundwater recharge pattern in a typical basement complex Formation at Federal College of Education, Osiele Abeokuta southwestern Nigeria. The survey involved thirty-four (34) vertical electrical sounding (VES) using Schlumberger electrode array at $200 \mathrm{~m}$ electrode separation. Seven geologic formations were revealed in their studies, viz topsoil, sandy clay, clayey sand, shale/clay, sandstone, fractured basement and fresh basement. It was concluded that the weathered and fractured basement in the study area constitutes the main aquiferous unit. Mosuro et al. (2011) carried out geophysical investigation for groundwater exploration at Kobape, via Abeokuta southwestern Nigeria using Schlumberger array for the vertical electrical sounding (VES) data acquisition. It was submitted that Kobape area lies within the sedimentary terrain of Dahomey Basin, which 
consist Abeokuta group and according to Agagu (1985). It was concluded based on the results of the VES data that there exist four to five geoelectric layers that their lithology is essentially sandy and highly resistive. The researchers reported that the promising aquiferous layer in the study area was observed at a depth of $270 \mathrm{~m}$ below the surface, and recommended that a borehole drilling should be carried out in the peak of the dry season in the area.

\section{Physiographic and geological setting of the study area}

The study area falls along Abeokuta-Sagamu Expressway in which Sagamu is a sedimentary terrain and Abeokuta town is Basement complex. The site lies between latitude $7^{0} 3^{\prime} 18^{\prime \prime}$ $\mathrm{N}$ to $7^{0} 3^{\prime} 25^{\prime \prime} \mathrm{N}$, and longitude $3^{0} 30^{\prime} 40^{\prime \prime} \mathrm{E}$ to $3^{0} 30^{\prime} 41^{\prime \prime} \mathrm{E}$ with an approximate area spread of $556.2 \mathrm{~km}^{2}$. Moloko-Asipa is located in Obafemi Owode Local Government area of Ogun State which shares boundaries with Odeda Local Government Area and Oyo state to the north, Sagamu and Ikene Local Government to the east and Ifo Local Government with Lagos state to the south (Fig. 1). The rejuvenated crystalline rocks found in the study area are dominated by granites, schist, gneiss and quartzite and are of Precambrian age to early Paleozoic age. The rocks extend from the north-eastern part of the Ogun state running southwest and dipping towards the coast (Ako 1979). Selby (1985) reported that rock often breaks down quickly to produce a zone of weathered materials of saprolite or laterite. The surface soils are usually underlain by red-brown silty clay which does not serve as a good aquifer, and according to Farquharson and Bullock (1992), basement aquifers occur within the weathered residue overburden (the regolith) and the fractured bedrock. Development of the regolith components is by shallow boreholes and wells which are liable to be drilled by lightweight percussion rigs as viable aquifers occur within fractured bedrock.

Development of bedrock components requires interaction with available storage in overlying or adjacent saturated regolith, or other suitable formations such as alluvium for effectiveness. Typical metamorphic rocks found in basement complex are characterized by various folds, structures of different degrees of complexity, faults and foliation. The rock

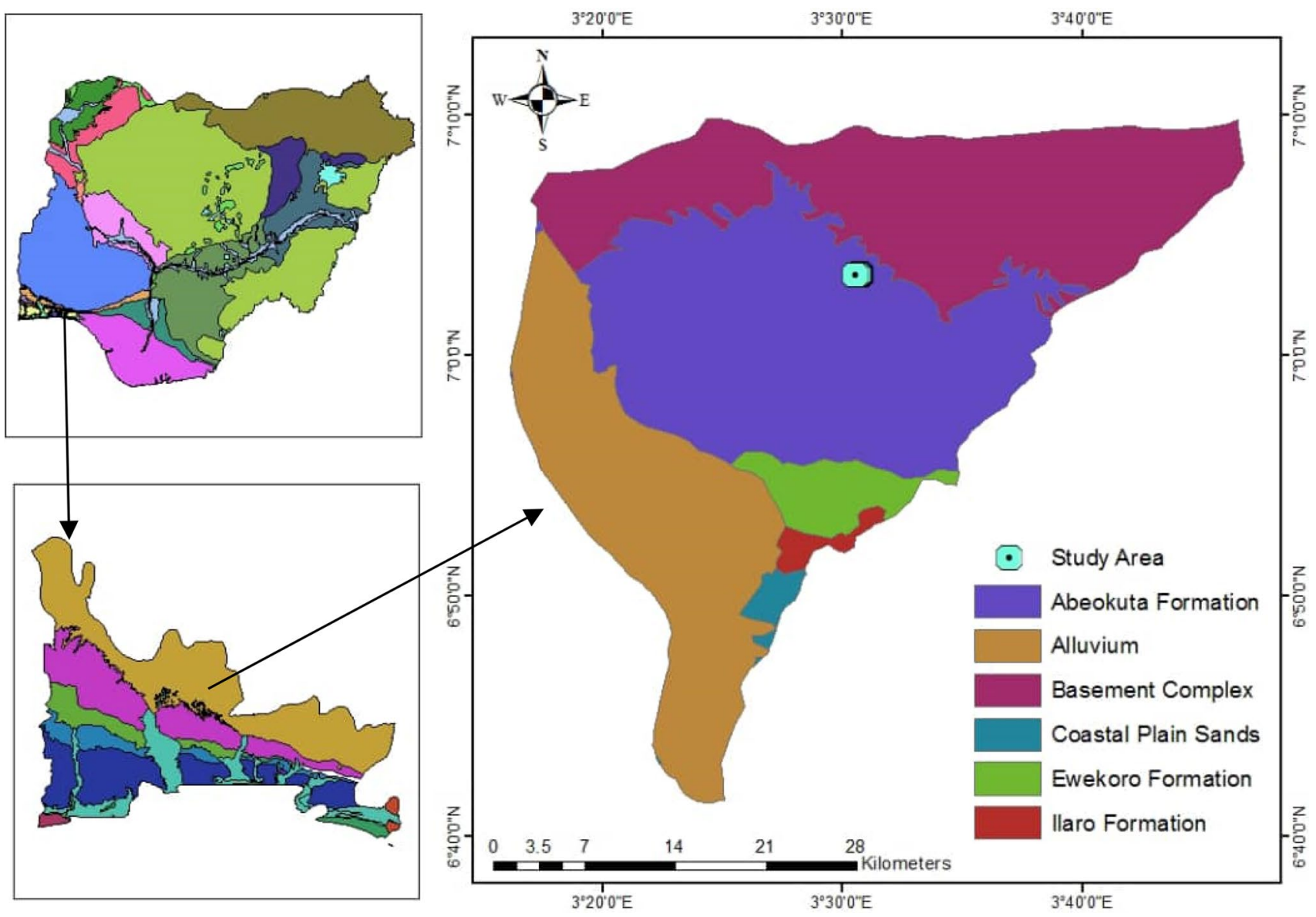

Fig. 1 Geological Map of Ogun State Showing the Study Area 
types that characterize the study area range from granite, schist, gneiss and pegmatite. The individual rocks have various hydrogeologic characteristics and belong to the stable plate, which was not subjected to intense tectonics in the past (Usman and Ibrahim 2017). Hence, the underground faulting system is minimal, and this has contributed to the problem of underground water occurrence in the area. The geology of Kobape shows that it lies within the sedimentary terrain of Dahomey Basin, which consists of Abeokuta group (Agagu 1985). This formation reveals sandstones, grits, siltstones, limestones, shales and sands lithologies (Ariyo and Adeyemi 2012). The extracted geology of the study area is shown in Fig. 1.

\section{Materials and methods}

Very low frequency electromagnetic (VLF-EM) profiling and vertical electrical sounding methods were employed in the survey. The VLF-EM survey was carried out using the ABEM WADI VLF instrument, while electrical resistivity meter was utilized for the resistivity data collection. The VLF-EM enables surveying for electrical conductors beneath the surface without any contact with the ground, and eight different traverses were carried out in the study area (Fig. 2). Electromagnetic field signals that are being generated worldwide from a high powered transmitter are essentially uniform in the atmosphere and can penetrate the ground to a depth of about $30 \mathrm{~m}$. The VLF signal transmitters generate a plane electromagnetic (EM) waves which consist of both the vertical electric field and horizontal magnetic field components; each perpendicular to the direction
Fig. 2 The Coordinate Layout of the VES Points and the VLFEM Traverses
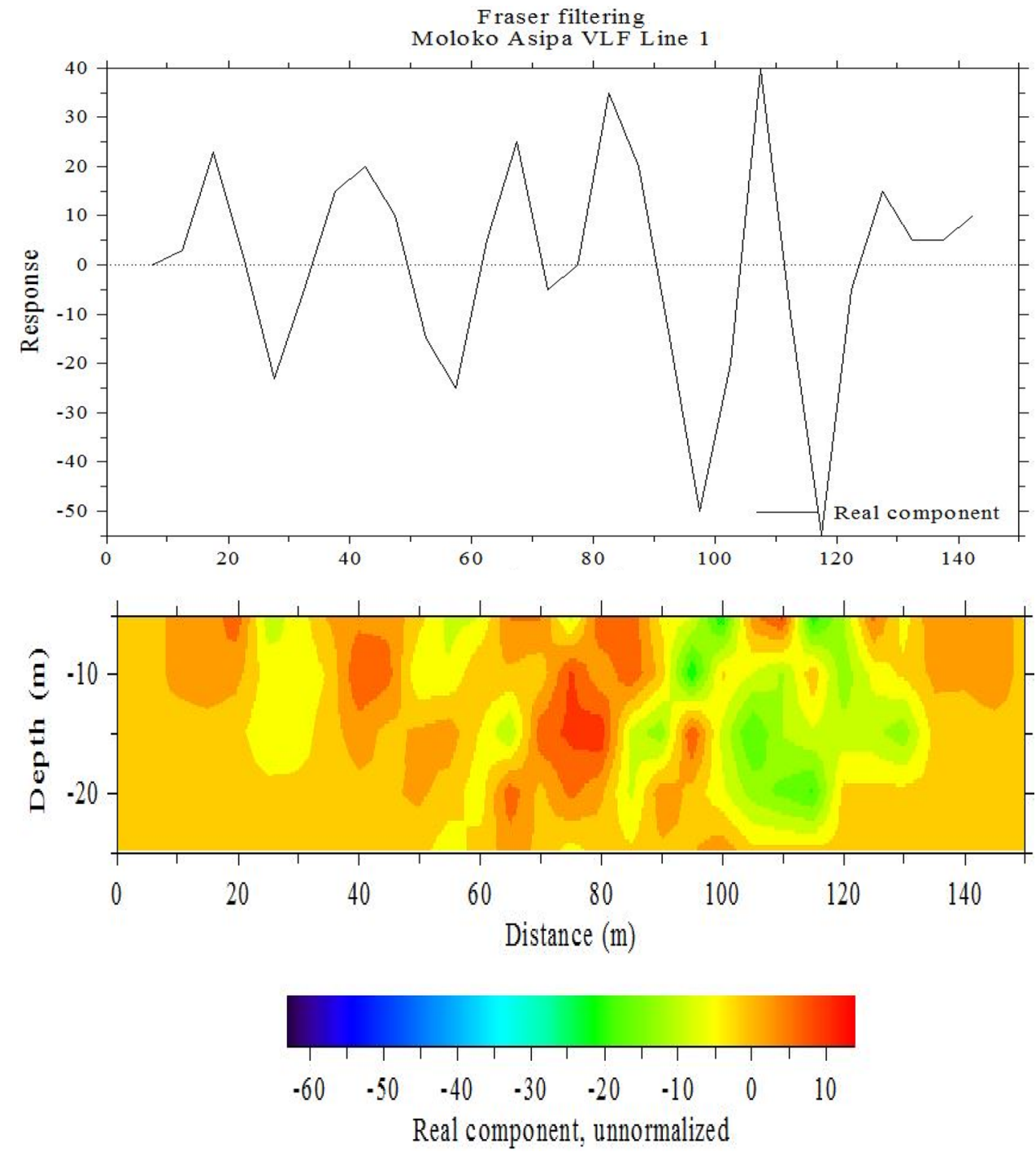
of propagation. The vertical electric fields induce electric currents, particularly on electrically conductive zones in the subsurface to produce secondary magnetic fields that are detectable at the surface through the deviation of the normal radiated field. The magnetic component of the VLF signal is mainly used for the field measurement. According to the basic electromagnetic (EM) theory, the primary EM field is shifted in phase when encountering a conductive body which then becomes the source of a secondary field. The VLF instrument detects the primary and secondary fields. It then separates the secondary field into real (in-phase) and imaginary (quadrature) components based on the phase lag of the secondary field. These two components of the secondary fields are sometimes referred to as the tilt $(\alpha)$ and ellipticity $(e)$.

A VLF receiver is tuned to a specific frequency within the range of $15-30 \mathrm{kHz}$ of the high powered transmitter and directs the signal towards the Earth's surface. The VLF receiver then measures the field tilts while the real and the imaginary components of the field data are being recorded to processing (Ndatuwong et al. 2013). In VLF-EM survey, the in-phase and quadrature are the most important field measurements and can be expressed as the normalized real and quadrature components of the vertical magnetic field. Equations 1 and 2 can be used to derive the apparent conductivity of the ground (Reynolds 1997).

$$
\text { real }=\frac{\operatorname{real}\left(H_{z}\right)}{\sqrt{\left[H_{x}^{2}-H_{y}^{2}\right]}}
$$

imaginary $=\frac{\operatorname{imaginary}\left(H_{z}\right)}{\sqrt{\left[H_{x}^{2}-H_{y}^{2}\right]}}$

where $H x, H y$ and $H z$ are the magnetic field components in $x, y$ and $z$ directions.

Linear inversion of the acquired real component of the field data involved the application of the Fraser and Karous-Hjelt filtering and processing. The filtering is done to remove geologic noise and the noise originating from the transmitter (Benson et al. 1997). A qualitative interpretation of VLF-EM data is based on the crossover points between the real and imaginary lines, which appears as positive peaks in the Fraser-filtered real curve. These regions constitute anomalous zones which can be attributed to the presence of vertical conductor or lateral contacts of different resistivity values beneath the surface (Srigutomo et al. 2005).

The process of Karous-Hjelt filtering yields a pseudosection of relative current density variation with depth. A higher value of relative current density corresponds to resistive subsurface structures and a lower value tending towards negative corresponds to a conductive subsurface structure. The application of Karous-Hjelt filtering process to the real component of the field signal reveals the distribution of the current density, which is displayed and interpreted as a map of current density (Benson et al. 1997). The filtering process, therefore, provides a visual indication of the depth of the various current concentrations and hence the spatial dispositions of subsurface geological features, such as mineral veins, faults, shear zones and stratigraphic conductors (Khalil et al. 2009).

Fraser Filter is another smoothening technique similar to the Karous-Hjelt filter which transforms the VLF anomalies to contours in such a way that proper crossovers are transformed to positive peak amplitude. Reverse crossovers, on the other hand, become negative values, thereby enhancing the signals of the conductive structures (Telford et al. 1990). The centre of the anomalous structure may fall directly under the peak of the Fraser filtered data. The advantages of the Fraser filter include (i) complete removal of DC bias and great attenuation of long wavelength signals; (ii) complete removal of Nyquist frequency related noise; (iii) phase shifts in all frequencies by $90^{\circ}$ and (iv) having the band-pass centered at a wavelength of five times the station spacing (Sundararajan et al. 2006; Khalil et al. 2009). Two-dimension image of Karous-Hjelt filter shows a typical inverted current density sections using a software; KHFfilt ver. 1.1a (Pirttijärvi 2004). The VLF-EM data are useful to obtain a qualitative view of the sub-structure, particularly after filtering the data and analysing the current density across the section. The results obtained from the VLF-EM survey with KHFfilt package give the Fraser outputs and 2-D subsurface conductivity images. The Fraser filter uses four consecutive data points in a situation where the data have been acquired at a regular interval. The sum of the first and second data point is subtracted from the sum of the third and fourth values and plotted at the midpoint between the second and third tilt-angle stations. The point of inflection or crossover point on the Fraser filtering curve indicates the presence of a target which the depth of occurrence can be estimated as half of the distance between the peak negative and peak positive amplitudes (Sriramulu et al. 2017).

A vertical electrical sounding (VES) using Schlumberger array method was employed to determine the depth of conductive zones and estimate the layers associated with the point under investigation. The array is capable of isolating successive hydrogeologic layers beneath the surface using their resistivity contrast (Mosuro et al. 2011). The observed field data, which is the ratio of the resulting voltage to the injected current, was obtained from the resistivity meter, and it is only a measure of the resistivity of the subsurface material. This measured resistance $(\mathrm{R})$ was multiplied by the corresponding Geometric Factor (a function of the electrode spacing and configuration) to obtain the apparent resistivity 
measured in Ohmmeter $(\Omega \mathrm{m})$ needed for the interpretation. The sounding curves for each point were obtained by plotting the computed apparent resistivity against the half current electrode spacing $(\mathrm{AB} / 2)$, and IPI2Win software was first used to perform an automatic approximation of the initial resistivity and thickness of the various geoelectric layers. The generated results were further processed with WinResist iteration to filter possible error from the equipment and smooth the sounding curves.

\section{Dar-Zarrouk parameter and its application}

The Dar-Zarrouk parameters (DZP) are the most essential parameters in electrical sounding prospecting, which can be used directly in aquifer protection studies and evaluation of hydrologic properties of the aquifer (Adeniji et al. 2013). The parameters are longitudinal conductance $(S)$ and transverse resistance $(T)$. The longitudinal unit conductance in $\Omega^{-1}$ is the ratio of the layer thickness $(h)$, to resistivity $(\rho)$ while the transverse unit resistance in $\Omega \mathrm{m}^{2}$ is the product of the layer thickness $(h)$ and resistivity $(\rho)$ shown in Eqs. 3 and 4 (Ahamefula et al. 2012).

Mathematically:

Longitudinal conductance $S=\frac{h}{\rho}$

Transverse resistance $T=h$

A geoelectric layer is always characterized by these two basic parameters; layer resistivity $\rho_{i}$ and layer thickness $h_{i}$ for every $i$ th layer (where $i=1$ for the surface layer and $n$ for number of layers)

$S=\sum_{i=1}^{n}\left(\frac{h_{i}}{\rho_{i}}\right)$

$T=\sum_{i=1}^{n}\left(h_{i} \rho_{i}\right)$

The sum of the entire longitudinal conductance for a layered ground is referred to as Dar-Zarrouk function and the sum of the corresponding transverse resistance is called Dar-Zarrouk variable as shown in Eqs. 5 and 6 (Isaac 2014).

\section{Results and discussions}

The processing of the VLF data generates a graph for real and imaginary component for each traverse and corresponding pseudo-sections which are the plots of depth versus station interval in 2-D inversion. Colour scales are usually shown beneath the 2-D inversion image which represents conductivity band. The conductivity band, generated from the processing of the obtained VLF measurements, ranges from -60 to $10 \%$ with a colour spectrum ranging from deep blue, turquoise blue, yellowish-green, yellow and orange to red. The red colour indicates the high current density (conductive body), while the dark blue colour indicates low current density (resistivity body) and the intermediate green colour reveals a moderate resistive bodies such as shear zone (Srigutomo et al. 2005; Sundararajan et al. 2006).

\section{VLF interpretation for traverse 1}

The Fraser filtering curve of the VLF responses obtained from traverse 1 shows relative distribution of conductive and resistive bodies of various amplitudes across the east-west direction. The maximum conductivity response of $40 \%$ was observed at position $108 \mathrm{~m}$ while a minimum conductivity response of $-55 \%$ occurs at lateral position of $116 \mathrm{~m}$. Other relatively high and low responses along the traverse indicate weakly conductive and resistive bodies at various depths. The 2-D inversion by Karous-Hjelt filtering revealed moderately resistive bodies from the base of the profile at position $82 \mathrm{~m}$ to $100 \mathrm{~m}$ close to the surface and same bodies are longitudinally distributed from 100 to $132 \mathrm{~m}$ along the traverse. Pocket of conductive material was observed close to the surface between 8 and $22 \mathrm{~m}, 36$ to $48 \mathrm{~m}$ and also from the base of the profile at position $62 \mathrm{~m}$ towards $88 \mathrm{~m}$ close to the surface (Fig. 3).

\section{VLF interpretation for traverse 2}

Traverse 2 Fraser filtering curve revealed maximum positive amplitude of $20 \%$ and minimum negative amplitude of $-15 \%$ at positions 68 and $92 \mathrm{~m}$ along the traverse, respectively. Another high negative amplitude of $-14 \%$ occurs at position $108 \mathrm{~m}$ which revealed the presence of another resistive body along the east-west direction of the profile. The 2-D inversion by Karous-Hjelt filtering revealed that no anomaly is present from the beginning of the traverse to around $38 \mathrm{~m}$ where a conductive zone is observed extending to $58 \mathrm{~m}$ along the traverse. Another conductive body is observed between $70 \mathrm{~m}$ from the base of the profile to $98 \mathrm{~m}$ towards the surface along the traverse (Fig. 4).

\section{VLF interpretation for traverse 3}

The Frazer filtering curve of traverse 3 has conductivity range of -25 to $16 \%$. The peak positive and negative responses were observed at $62 \mathrm{~m}$ and $142 \mathrm{~m}$ in the east-west direction of the profile. Another high conductivity response of $+15 \%$ was also observed at position $72-78 \mathrm{~m}$ showing the presence of a conductive anomaly 
Fig. 3 Fraser and Karous-Hjelt representation for traverse 1
Fraser filtering

Moloko Asipa VLF Line 2
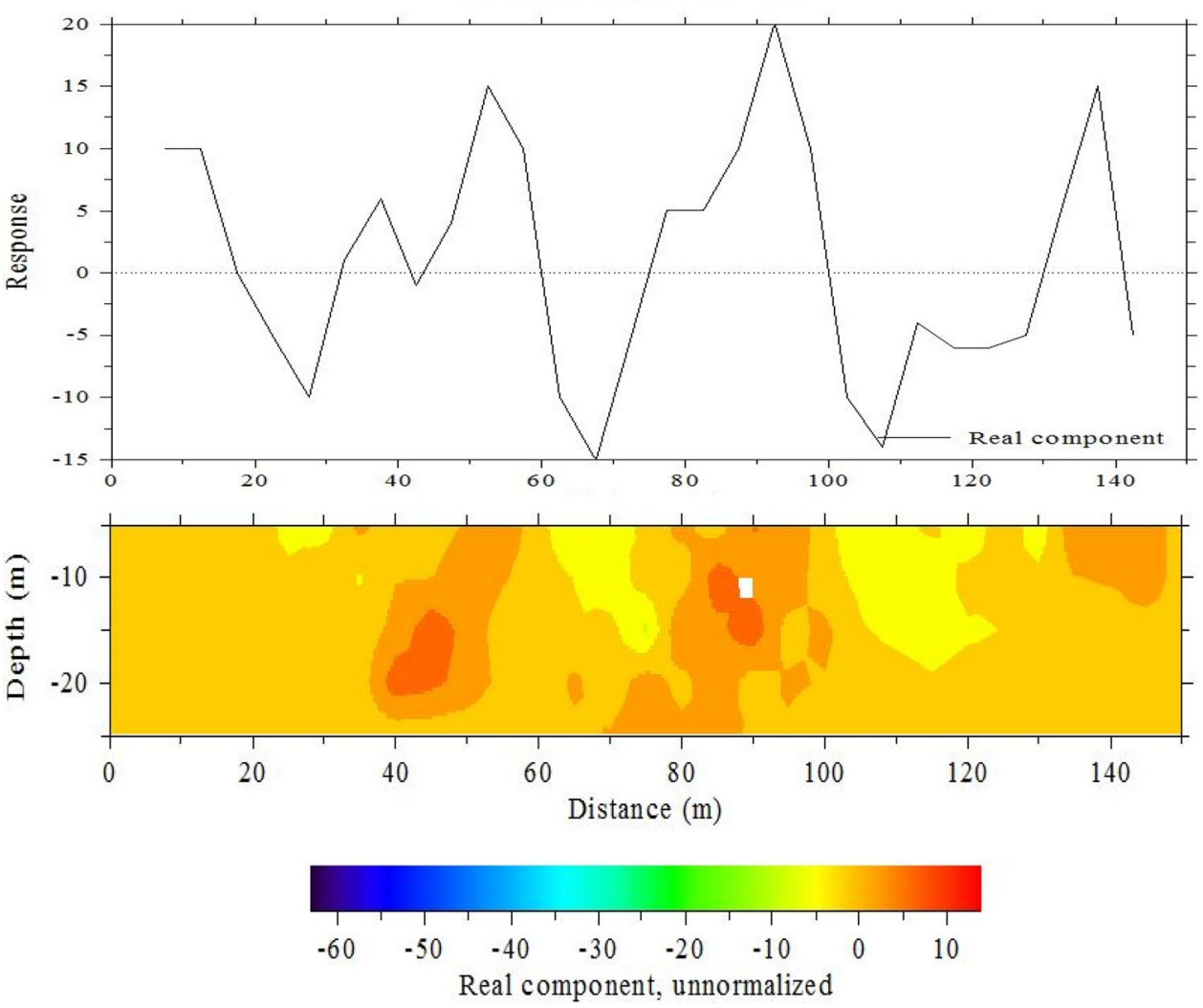

Fig. 4 Fraser and Karous-Hjelt representation for traverse 2

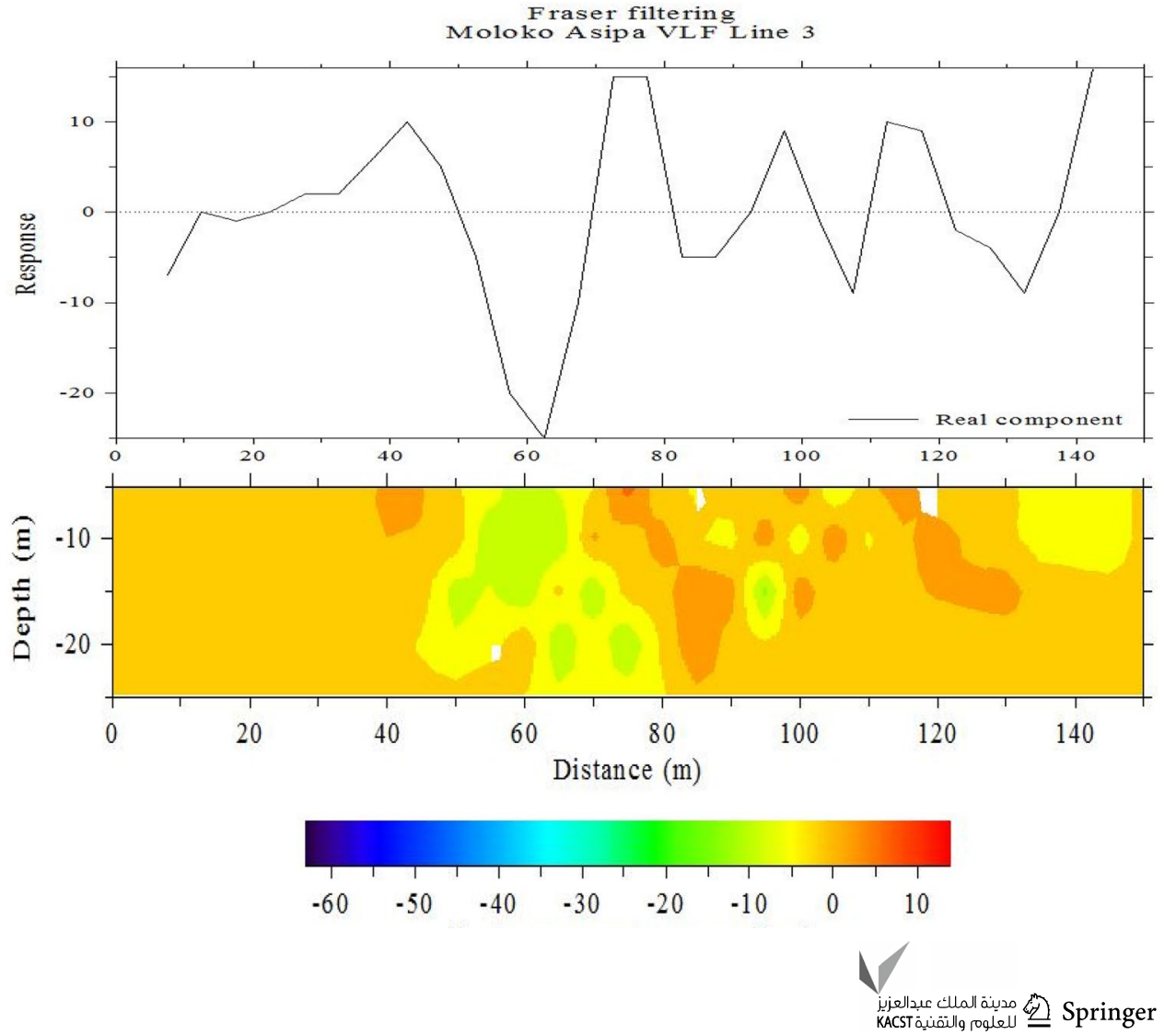


in the region. The 2-D inversion by Karous - Hjelt filtering revealed the presence of a resistive anomaly between 44-80, 92-98 and 132-148 m along the traverse. Scattered conductive bodies were also observed to vary laterally between positions 38-132 m along the traverse (Fig. 5).

\section{VLF interpretation for traverse 4}

Traverse 4 revealed a peak negative anomalous response of $-28 \%$ at position $70 \mathrm{~m}$ and the highest conductivity response is $23 \%$ at position $135 \mathrm{~m}$. Other relatively dwarf peaks in the order of $18 \%$ correspond to the weakly conductive material distribution across the traverse. The 2D-Inversion by Karous-Hjelt filtering revealed the material distribution along traverse to be a complex varying mixture of resistive to conductive bodies at closely varying intervals. The investigation carried out on this traverse covers up to $200 \mathrm{~m}$ thereby revealing the subsurface structure up to a depth of $30 \mathrm{~m}$ (Fig. 6).

\section{VLF interpretation for traverse 5}

The Fraser filtering curve from the measurement taken from traverse 3 has a maximum positive amplitude response of $23 \%$ at position $112 \mathrm{~m}$ and minimum negative amplitude response of $-15 \%$ at position 122 and $132 \mathrm{~m}$ along the east-west direction of the traverse. The 2-D inversion by Karous-Hjelt filtering revealed moderately resistive anomaly of about $12 \mathrm{~m}$ thickness between $42-62$, 90-100 and 130-148 $\mathrm{m}$ along the traverse. The high conductivity responses from the Fraser filtering curve correspond to the bodies observed from the base of the profile at $52 \mathrm{~m}$ to $78 \mathrm{~m}$ on the surface. Other isolated conductive bodies were observed between 102 and $132 \mathrm{~m}$ in the North-South direction of the profile (Fig. 7).

\section{VLF interpretation for traverse 6}

The Frazer filtering curve of the measurements from traverse 6 revealed has conductivity range of -16 to $18 \%$. The peak positive and negative amplitudes were observed at
Fig. 5 Fraser and Karous-Hjelt representation for traverse 3

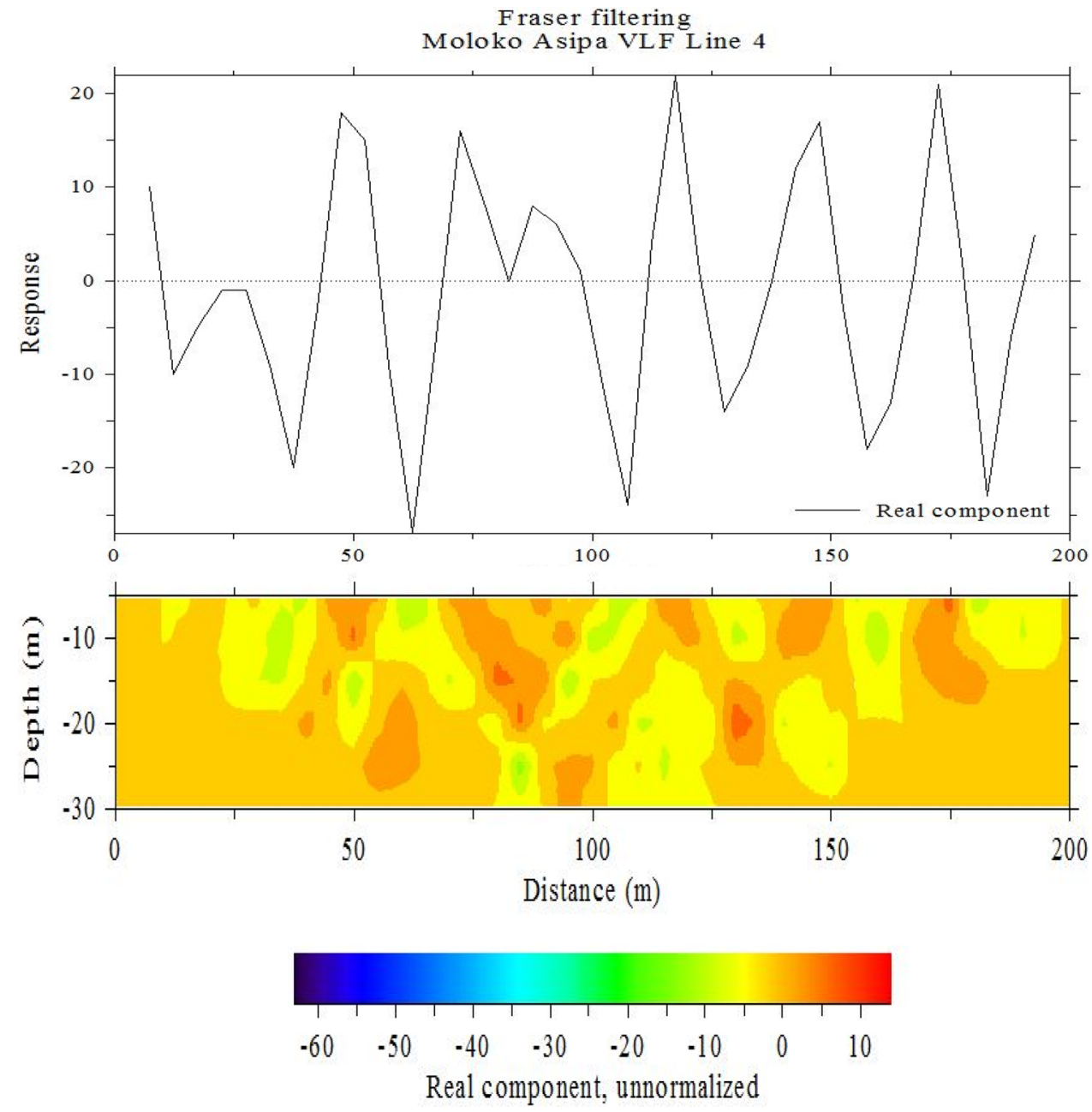


Fig. 6 Fraser and Karous-Hjelt representation for traverse 4
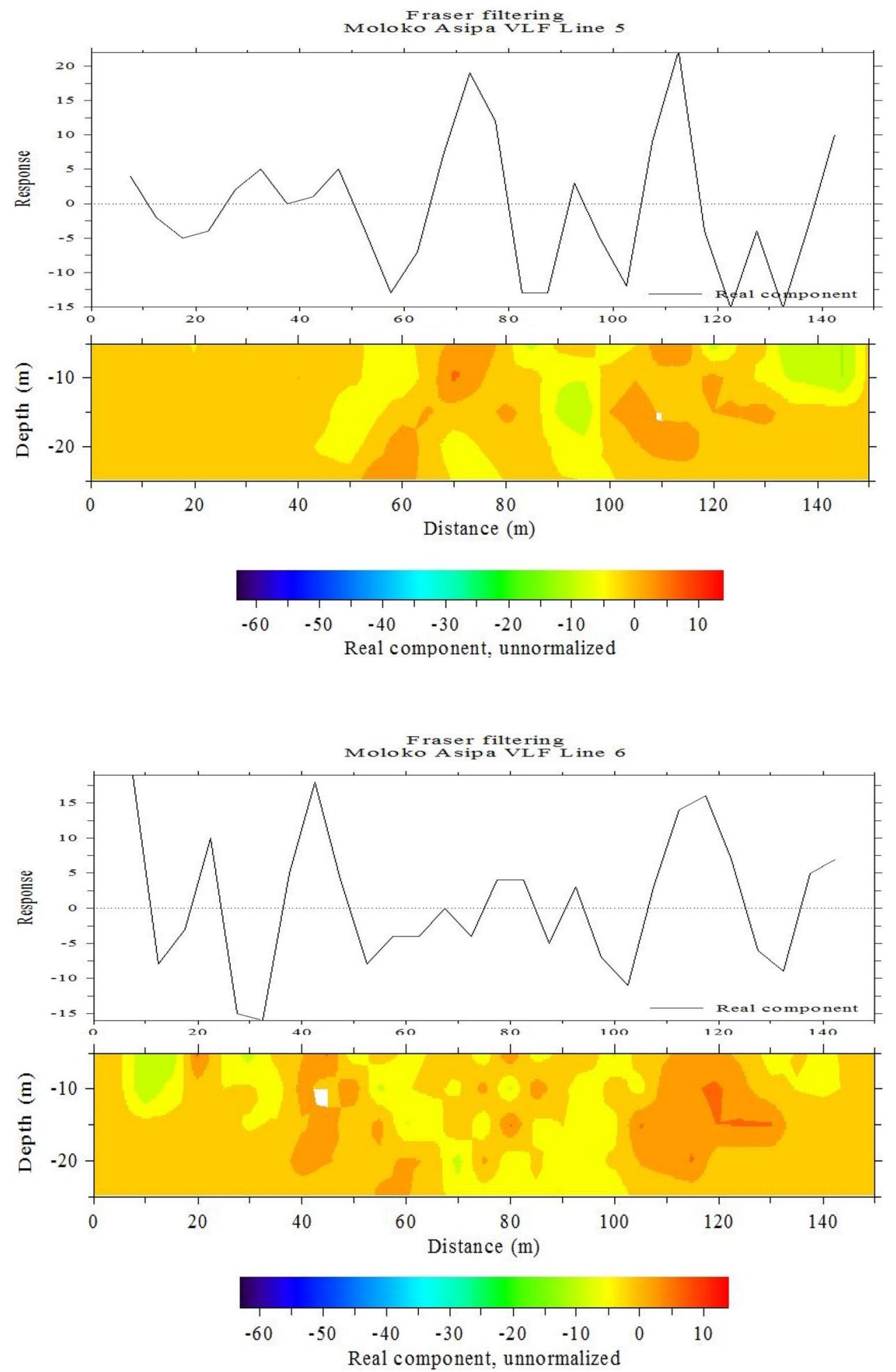

Fig. 7 Fraser and Karous-Hjelt representation for traverse 5 between 8 and $16 \mathrm{~m}$ in the East-West direction. Other resistive bodies were observed at position 60 and $100 \mathrm{~m}$ in the North-South direction of the profile. Weakly conductive bodies, however, occur at position $40-48 \mathrm{~m}$ and 102-132 $\mathrm{m}$ along the profile (Fig. 8). ring revealed very small moderately resistive bod close to the surface with an average thickness of $12 \mathrm{~m}$ position $42 \mathrm{~m}$ and $32 \mathrm{~m}$ in the East-West direction of the profile, respectively. Another high response of $16 \%$ corresponding to conductive anomaly was observed between 110 and $120 \mathrm{~m}$. The 2-D inversion image by Karous-Hjelt 
Fig. 8 Fraser and Karous-Hjelt representation for traverse 6

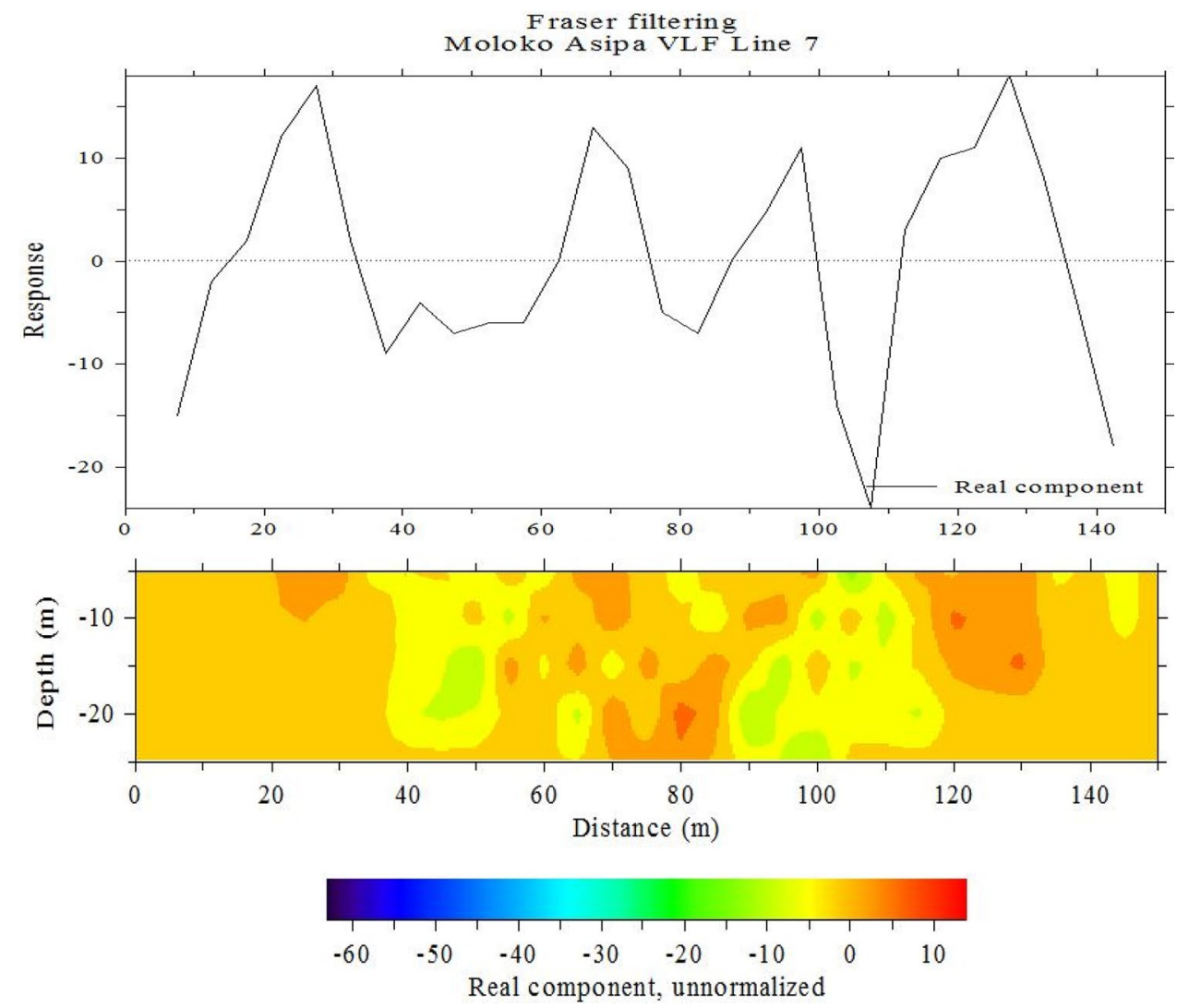

\section{VLF interpretation for traverse 7}

The peak negative and positive responses shown on the Frazer filtering curve of traverse 7 VLF measurements are $-25 \%$ and $19 \%$ and occur at positions $108 \mathrm{~m}$ and $128 \mathrm{~m}$ in the East-West direction of the profile. The 2-D inversion by Karous-Hjelt filtering revealed weakly resistive region at 38-50 $\mathrm{m}$ and $90-120 \mathrm{~m}$ in the North-South direction of the profile. Moderately conductive bodies were, however, observed close to the surface between 20-32 m, 66-72 m, $104-122 \mathrm{~m}$ and between 70 and $85 \mathrm{~m}$ at the base of the profile (Fig. 9).

\section{VLF interpretation for traverse 8}

The Frazer filtering curve of the measurements taken from traverse 7 has peak negative and positive amplitudes $-22 \%$ and $22 \%$ at $72 \mathrm{~m}$ and $88 \mathrm{~m}$ in the East-West direction of the profile. Relatively weak amplitude of an average of $\pm 15 \%$ on the traverse indicates weakly conductive and resistive bodies of various depths along the traverse. The 2-D inversion by Karous-Hjelt filtering revealed moderately resistive bodies at $50-90 \mathrm{~m}$ and $96-132 \mathrm{~m}$ in the North-South direction of the profile (Fig. 10).

\section{VES results}

The nature of the VES curves obtained from the analysis of each sounding results indicates the interplay between low and high resistivity layers in the study area. The output is the inverse resistivity model providing layer-wise distribution of resistivity value and thickness of the corresponding layer with curve types are shown in Table 1. Most of the resulting models produced a low RMS relative error of the order of $2 \%$. The resistivity values extracted from Loke (2000) for common rocks and soil materials in the survey area were used to categorize the lithology of the VES data into geoelectric layers (Table 2).

Four geoelectric layers ranging from sandy topsoil, sandy horizon, and weathered layer to fresh basement were inferred at VES 1 with resistivity value of 564, 3592, 726 and 17,204 $\Omega \mathrm{m}$, respectively. The respective depths of the first three layers are $0.5,1.3$ and $10.3 \mathrm{~m}$ while that of the last layer cannot be determined. The curve type generated from WinResist iteration is $\mathrm{KH}$ type $\left(\rho_{1}<\rho_{2}>\rho_{3}<\rho_{4}\right)$ as shown in Fig. 11. $\mathrm{H}$ type curves in a typical basement complex environment that contains a low resistivity intermediate layer underlain and overlain by more resistant materials are commonly water saturated. Such regions are often characterized wit high porosity, low specific yield and low permeability. The main 
Fig. 9 Fraser and Karous-Hjelt representation for traverse 7
Fraser filtering

Moloko Asipa VLF Line 8
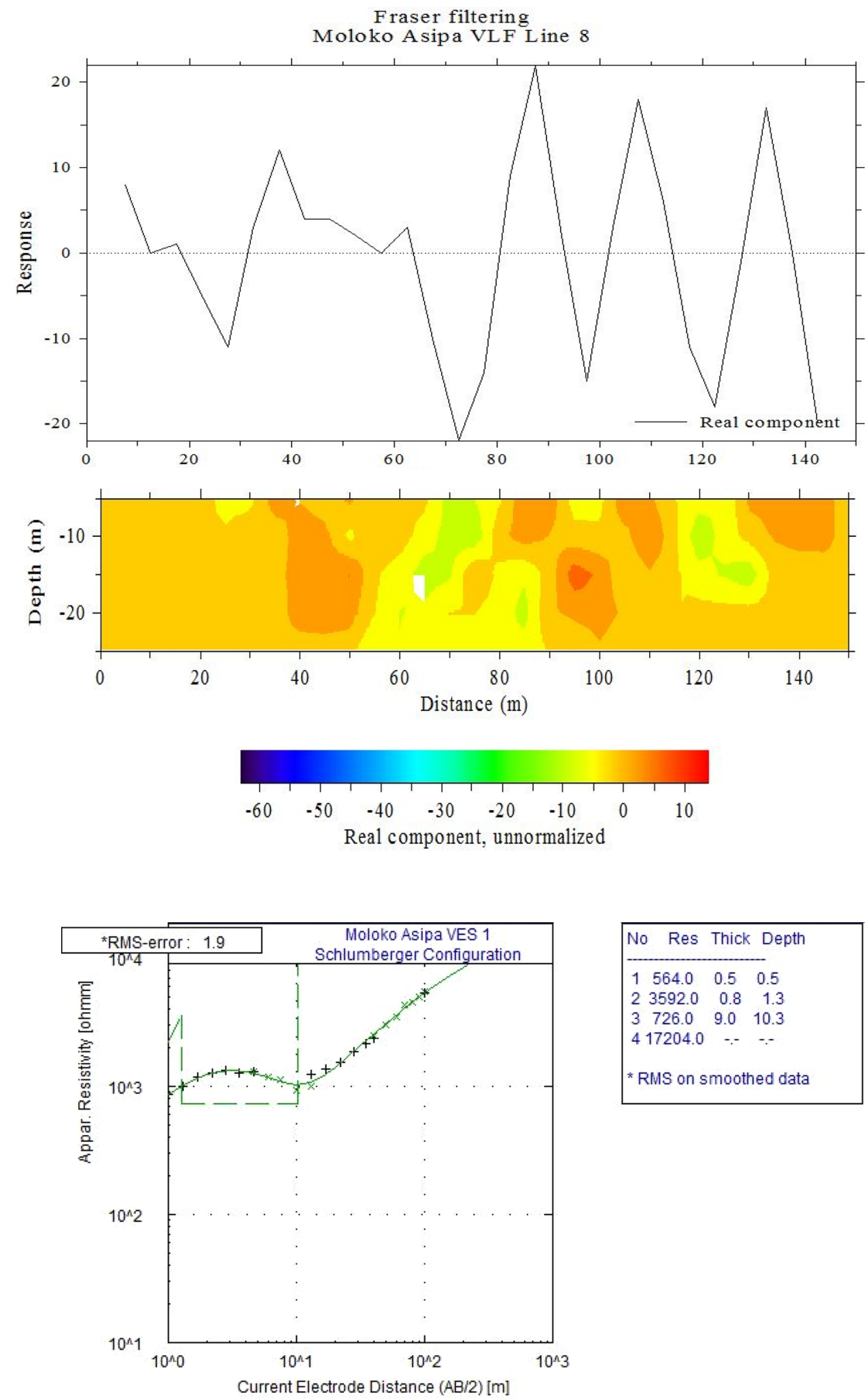

Fig. 10 Fraser and KarousHjelt representation for traverse 8 aquifer is usually found at the base of the weathered profile (Ariyo and Adeyemi 2013).

There are four geoelectric layers which are sandy topsoil, sandy horizon, weathered layer and fresh basement at VES 2 with corresponding resistivity values of 3596 , 1406,725 and $27,995 \Omega \mathrm{m}$. The relative depths of the layers are $0.5,5.8,5.7 \mathrm{~m}$ and that of the last layer cannot be determined. QH-type curve where $\rho_{1}>\rho_{2}>\rho_{3}<\rho_{4}$ is 
Table 1 Summary of the VES geoelectric parameters

\begin{tabular}{|c|c|c|c|c|c|c|}
\hline VES No & No of layers & Resistivity $(\Omega \mathrm{m})$ & Thickness (m) & Depth (m) & Lithology & Curve Type \\
\hline \multirow[t]{4}{*}{1} & 1 & 564 & 0.5 & 0.5 & Topsoil & \multirow[t]{4}{*}{ KH } \\
\hline & 2 & 3592 & 0.8 & 1.3 & Sandstone & \\
\hline & 3 & 726 & 9.0 & 10.3 & Weathered Layer & \\
\hline & 4 & 17,204 & - & - & Fresh Basement & \\
\hline \multirow[t]{4}{*}{2} & 1 & 3596 & 0.5 & 0.5 & Topsoil & \multirow[t]{4}{*}{$\mathrm{QH}$} \\
\hline & 2 & 1406 & 5.8 & 6.3 & Sandstone & \\
\hline & 3 & 725 & 5.7 & 12 & Weathered Layer & \\
\hline & 4 & 27,995 & - & - & Fresh Basement & \\
\hline \multirow[t]{3}{*}{3} & 1 & 1448.3 & 1.6 & 1.6 & Topsoil & \multirow[t]{3}{*}{$\mathrm{H}$} \\
\hline & 2 & 859.5 & 19.8 & 21.4 & Weathered Layer & \\
\hline & 3 & $56,382.1$ & - & - & Fresh Basement & \\
\hline \multirow[t]{3}{*}{4} & 1 & 1179 & 0.71 & 0.71 & Topsoil & \multirow[t]{3}{*}{ A } \\
\hline & 2 & 1753 & 25.4 & 26.1 & Sandstone & \\
\hline & 3 & 10,285 & - & - & Fresh Basement & \\
\hline \multirow[t]{5}{*}{5} & 1 & 1241 & 0.5 & 0.5 & Topsoil & \multirow[t]{5}{*}{ KHKA } \\
\hline & 2 & 4333 & 0.8 & 1.3 & Sandstone & \\
\hline & 3 & 635 & 2.2 & 3.6 & Weathered Layer & \\
\hline & 4 & 4829 & 64.9 & 68.5 & Sandstone & \\
\hline & 5 & 12,679 & - & - & Fresh Basement & \\
\hline \multirow[t]{4}{*}{6} & 1 & 825 & 0.5 & 0.5 & Topsoil & \multirow[t]{4}{*}{$\mathrm{KH}$} \\
\hline & 2 & 1378 & 0.8 & 1.3 & Sandstone & \\
\hline & 3 & 972 & 8.4 & 9.7 & Weathered Layer & \\
\hline & 4 & 6608 & - & - & Fresh Basement & \\
\hline \multirow[t]{3}{*}{7} & 1 & 341 & 0.6 & 0.6 & Topsoil & \multirow[t]{3}{*}{ A } \\
\hline & 2 & 882 & 13.2 & 13.8 & Weathered Layer & \\
\hline & 3 & 30,043 & - & - & Fresh Basement & \\
\hline \multirow[t]{3}{*}{8} & 1 & 1735 & 0.5 & 0.5 & Topsoil & \multirow[t]{3}{*}{$\mathrm{H}$} \\
\hline & 2 & 907 & 9.0 & 9.5 & Weathered Layer & \\
\hline & 3 & 4576 & - & - & Fresh Basement & \\
\hline \multirow[t]{4}{*}{9} & 1 & 6139 & 0.5 & 0.5 & Topsoil & \multirow[t]{4}{*}{$\mathrm{QH}$} \\
\hline & 2 & 2021 & 1.7 & 2.2 & Sandstone & \\
\hline & 3 & 1000 & 9.8 & 12.0 & Weathered Layer & \\
\hline & 4 & 5539 & - & - & Fresh Basement & \\
\hline \multirow[t]{4}{*}{10} & 1 & 1092 & 0.5 & 0.5 & Topsoil & \multirow[t]{4}{*}{ HA } \\
\hline & 2 & 472 & 1.9 & 2.4 & Clayey Sand & \\
\hline & 3 & 804 & 12.1 & 14.5 & Weathered Layer & \\
\hline & 4 & 3721 & - & - & Fresh Basement & \\
\hline
\end{tabular}

revealed by the iteration carried out for this second sounding point (Fig. 12).

\begin{tabular}{ll}
\hline Material & Resistivity $(\Omega \mathrm{m})$ \\
\hline Alluvium & $10-800$ \\
Sand & $60-1000$ \\
Clay & $1-100$ \\
Groundwater & $10-100$ \\
Sandstone & $8-4 \times 10^{3}$ \\
Shale & $20-2 \times 10^{3}$ \\
Limestone & $50-4 \times 10^{3}$ \\
Granite & $5000-1,000,000$
\end{tabular}

The geoelectric layers of VES 3 show that it consists of three layers, namely sandy topsoil, weathered layer and fresh basement with corresponding thickness of 1.6 and $19.8 \mathrm{~m}$ while the thickness of the third layer cannot be determined. The resistivity values of the layers are 1448.3, 859.5 and $56,382.1 \Omega \mathrm{m}$ from the topsoil to fresh basement. The curve type for this station is $\mathrm{H}\left(\rho_{1}>\rho_{2}<\rho_{3}\right)$ given that this curve type has the main aquifers found at the base of the weathered profile (Fig. 13). 
Fig. 11 Layer model interpretation for VES 1

Fig. 12 Layer model interpretation for VES 2

Fig. 13 Layer model interpretation for VES 3

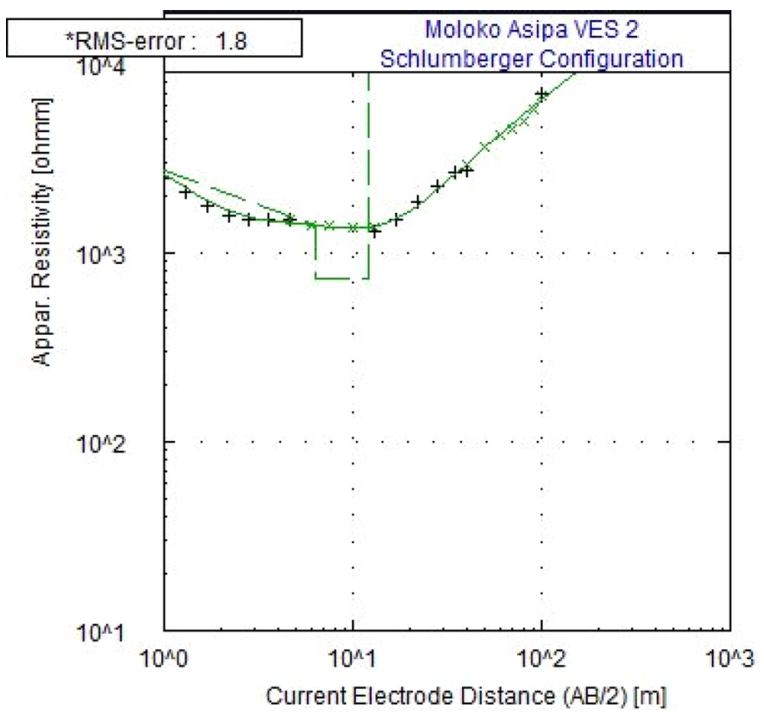

\begin{tabular}{|llll|}
\hline No & Res & Thick & Depth \\
\hline 1 & 3596.0 & 0.5 & 0.5 \\
2 & 1406.0 & 5.8 & 6.3 \\
3 & 725.0 & 5.7 & 12.0 \\
4 & 27995.0 & --- & -- \\
* & & & \\
RMS on smoothed data
\end{tabular}

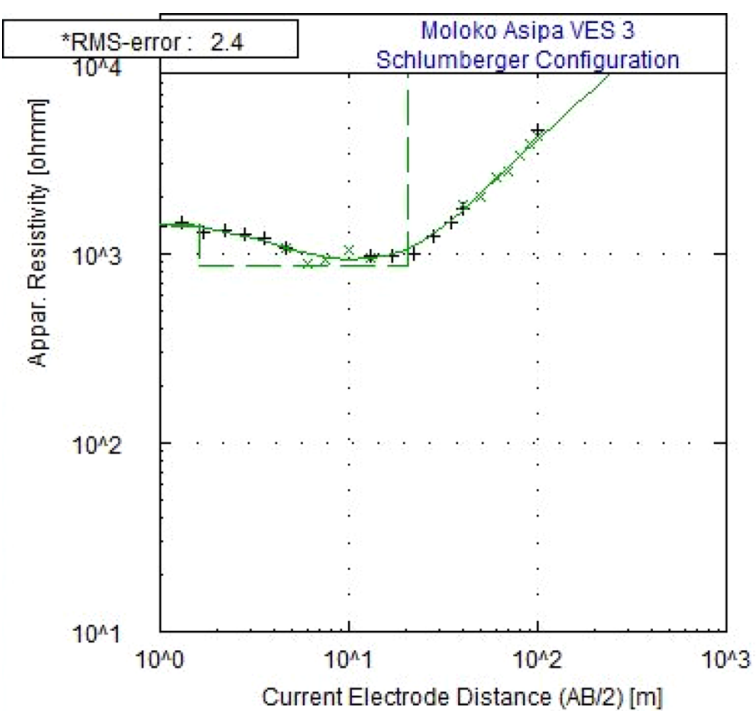

\begin{tabular}{|llll}
\hline No & Res & Thick & Depth \\
\hline 1 & 1448.3 & 1.6 & 1.6 \\
2 & 859.5 & 19.0 & 20.6 \\
3 & 56382.1 & -- & -- \\
& & & \\
* RMS on smoothed data
\end{tabular}

RMS on smoothed data

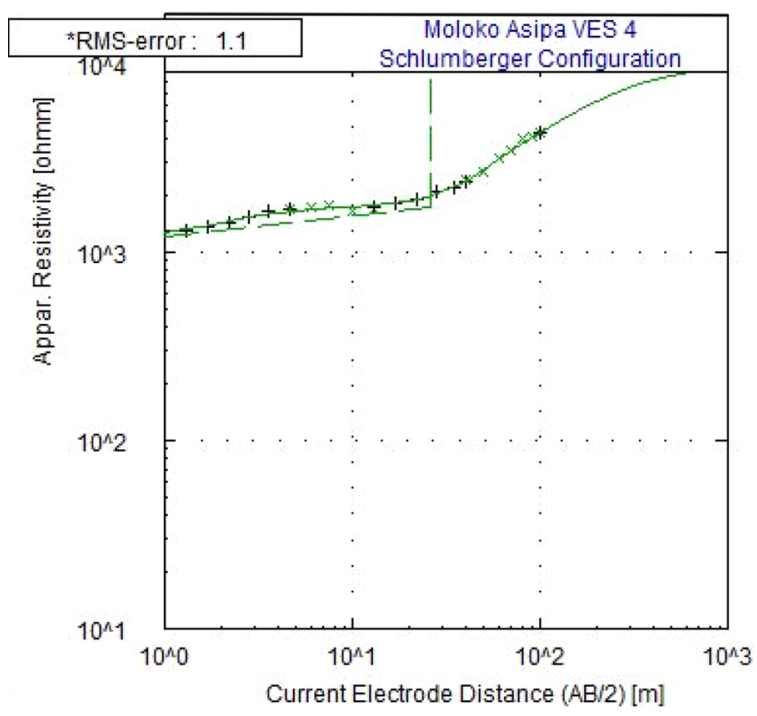


Three geoelectric layers inferred as sandy topsoil, weathered layer and fresh basement with resistivity values of 1179 , 1753 and $10,285 \Omega \mathrm{m}$ are shown at VES 4 with respective depths of 0.71 and $26.1 \mathrm{~m}$ for the first two layers while the depth of the third layer cannot be determined (Fig. 14). The WinResist iteration for this sounding point reveals A-type curve $\left(\rho_{1}<\rho_{2}<\rho_{3}\right)$.

The layer model interpretation for VES 5 reveals five layers ranging from sandy topsoil, sandy horizon, weathered layer, sandstone to fresh basement with corresponding resistivity values of $1241,4333,635,4829$ and $12,679 \Omega \mathrm{m}$. The relative thicknesses of the layers are $0.5,0.84,2.23,64.9 \mathrm{~m}$ where that of the last layer cannot be determined. The curve type from the iteration for this fifth sounding point is KHKA-type showing that $\rho_{1}<\rho_{2}>\rho_{3}<\rho_{4}>\rho_{5}$ (Fig. 15).

The sixth sounding also reveals four geoelectric layers: sandy topsoil, sandstone, weathered layer and fresh basement, with resistivity values of $825,1378,972$ and $6608 \Omega \mathrm{m}$ and respective thicknesses of $0.5,0.8$ and $8.4 \mathrm{~m}$ as the thickness of the fresh basement cannot be determined. KH-type curve $\left(\rho_{1}<\rho_{2}>\rho_{3}<\rho_{4}\right)$ is thus revealed from the iteration carried out on the sounding data (Fig. 16).

Three geoelectric layers ranging from sandy Topsoil, Weathered Layer to Fresh Basement with A-type curve $\left(\rho_{1}<\rho_{2}<\rho_{3}\right)$ were revealed from the iteration of VES 7 data. The resistivity values of the layers are 341, 882 and $30,043 \Omega \mathrm{m}$ with corresponding thickness of $0.6,13.2 \mathrm{~m}$ and undetermined thickness of the last layer (Fig. 17).

Three geoelectric layers were also revealed on VES 8 section with resistivity values of 1735,907 and $4576 \Omega \mathrm{m}$ and respective thickness of $0.5,9.5 \mathrm{~m}$ and that of the last layer cannot be determined. The layers are sandy Topsoil, Weathered Layer and Fresh Basement with H-type curve
Fig. 14 Layer model interpretation for VES 4

Fig. 15 Layer model interpretation for VES 5

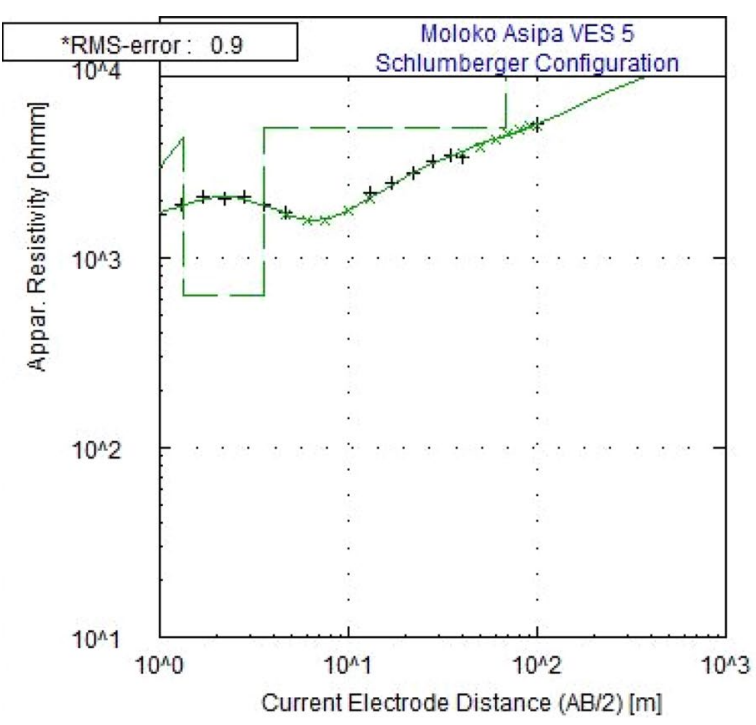

\begin{tabular}{|llll}
\hline No & Res & Thick & Depth \\
\hline 1 & 1241.0 & 0.5 & 0.5 \\
2 & 4333.0 & 0.8 & 1.3 \\
3 & 635.0 & 2.2 & 3.6 \\
4 & 4829.0 & 64.9 & 68.5 \\
5 & 12679.0 & --- & --- \\
* RMS on smoothed data
\end{tabular}

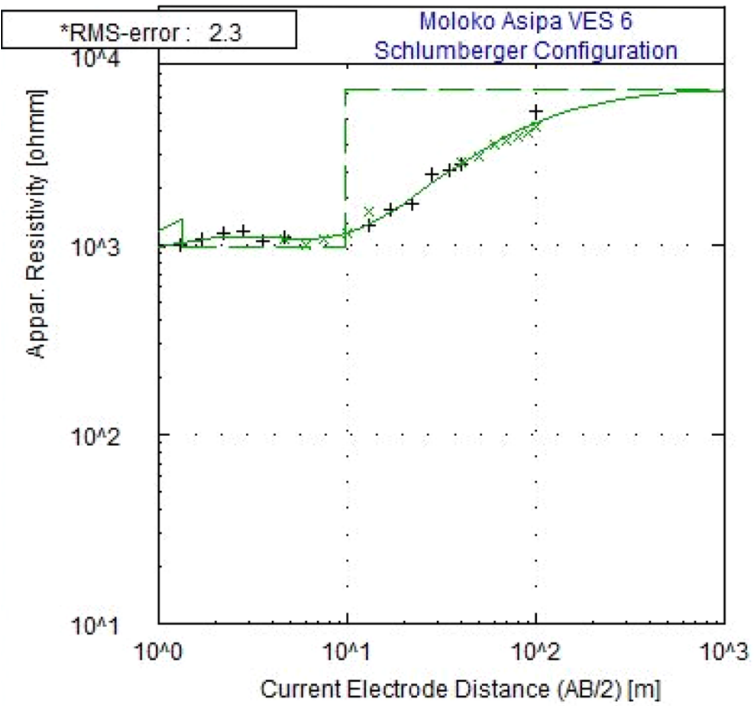


Fig. 16 Layer model interpretation for VES 6

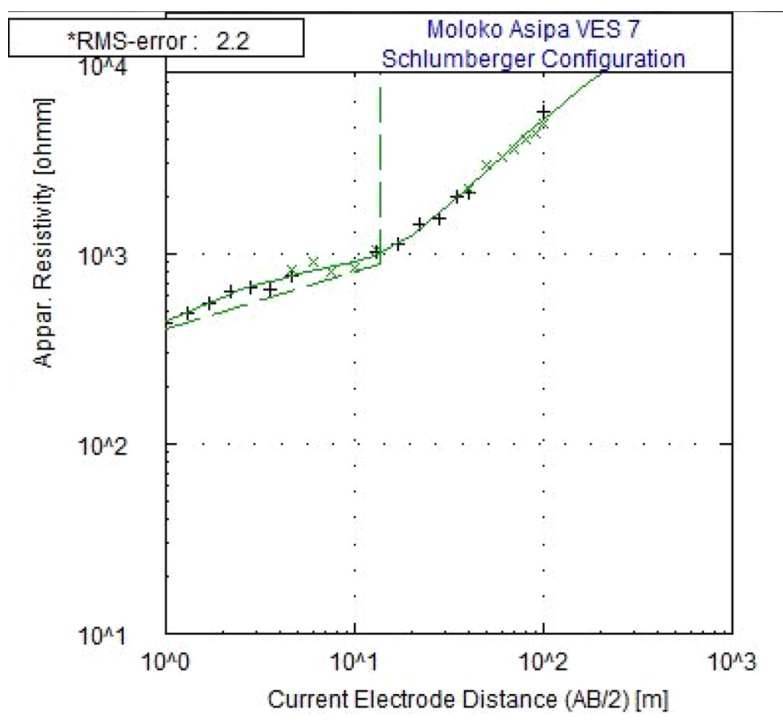

Fig. 17 Layer model interpretation for VES 7

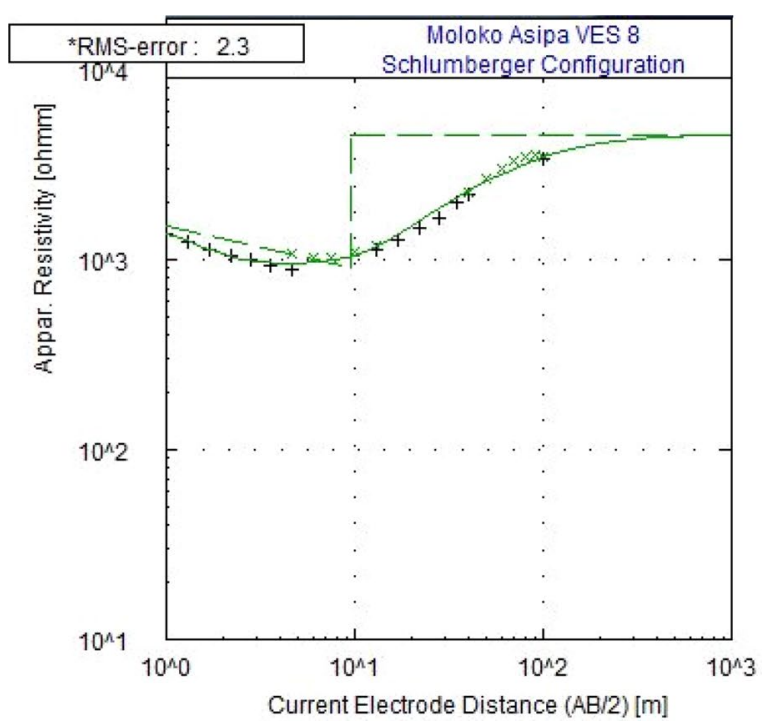

$\left(\rho_{1}>\rho_{2}<\rho_{3}\right)$ as revealed from the resistivity iteration in Fig. 18.

The ninth sounding reveals four geoelectric layers: sandy topsoil, sandstone, weathered layer and fresh basement, with resistivity values of $6139,2021,1000$ and $5539 \Omega \mathrm{m}$ with corresponding thickness of $0.5,1.7$ and $9.8 \mathrm{~m}$ as the thickness of the fresh basement cannot be determined. QH-type of curve is thus revealed from the iteration carried out with WinResist (Fig. 19) revealing that $\rho_{1}>\rho_{2}>\rho_{3}<\rho_{4}$.

Four geoelectric layers were also recorded at VES 10 ranging from sandy topsoil, sandy horizon and weathered layer to fresh basement with corresponding resistivity values of $1092,472,804$ and $3721 \Omega \mathrm{m}$. The relative thicknesses of the layers are $0.5,2.4$ and $14.5 \mathrm{~m}$ while that of the last layer cannot be determined. The curve type of the iteration for this sounding point is HA-type revealing that the $\rho_{1}>\rho_{2}<\rho_{3}<\rho_{4}$ (Fig. 20).
The characteristic longitudinal unit conductance prepared with Eq. 5 provides an estimate of the Dar-Zarrouk parameters for all the VES locations (Table 4) and was used to evaluate the protective capacity rating of the study area. The aquifer protective capacity characterization is based on the values of the longitudinal layer conductance of the overburden rock units at each sounding stations. The standard values for Longitudinal Conductance and aquifer protective capacity rating are shown in Table 3. The application of these parameters is aimed at unraveling the potential for viable groundwater exploration in the study area. The ability of the earth medium to acts as a natural filter to percolating fluid and retard or filter percolating ground surface polluting fluid is a measure of its protective capacity (Olorunfemi and Dan-Hassan 1999). The highly impervious sandy or clayey overburden, which is characterized by relatively high longitudinal 
Fig. 18 Layer model interpretation for VES 8

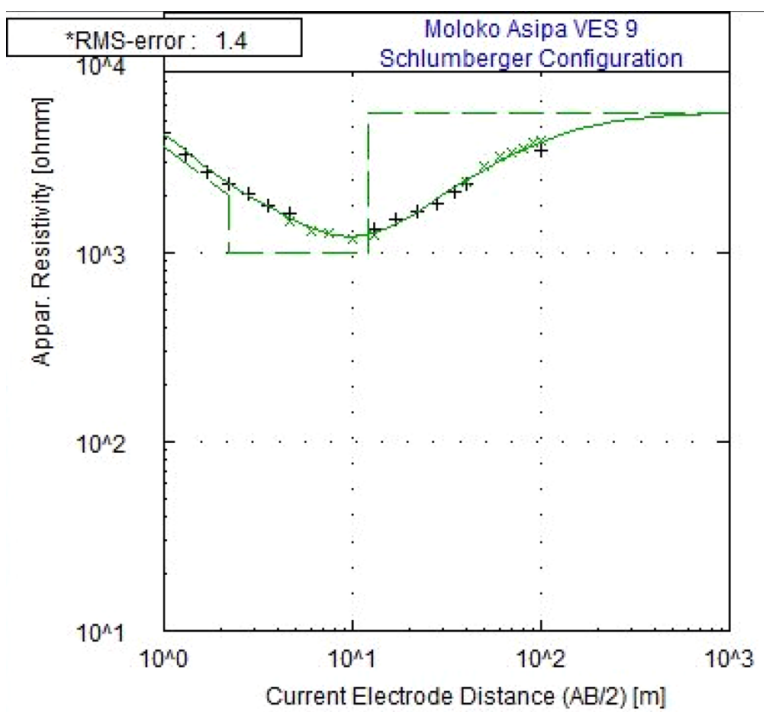

Fig. 19 Layer model interpretation for VES 19

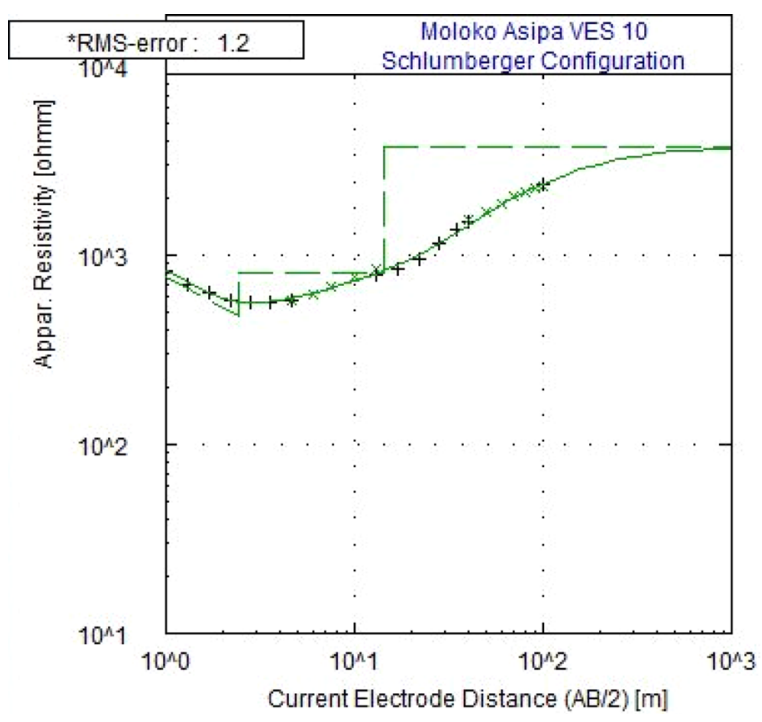

conductance, offers a better protection to the underlying aquifer; hence, the protective capacity inferred from the study area is poor as the values of the longitudinal unit conductance $(S)$ range between 0.010 and 0.024 mhos (Table 4).

The potential for groundwater exploration in the study area is therefore evaluated based on the weathered layer thickness and the aquifer protective capacity. The inferred weathered layers constitute the water saturated zones which are aquifer units. The interpretation carried out is useful to provide information on the curve type and determine the geoelectric properties of the subsurface layers. The geoelectric section was drawn for the closest sounding in the study area to provide information on the subsurface geology (Fig. 21).

\section{Conclusion}

The geophysical investigation for groundwater exploration in Moloko-Asipa was carried out using VLF-EM and VES methods of survey. The interpreted results from the VLF-EM survey revealed the nature of the subsurface in the area to an average depth of $25 \mathrm{~m}$ and were inferred to be dominated with highly resistive material. These results were verifiable from the VES interpretation that revealed the subsurface structure of the area investigated to be 


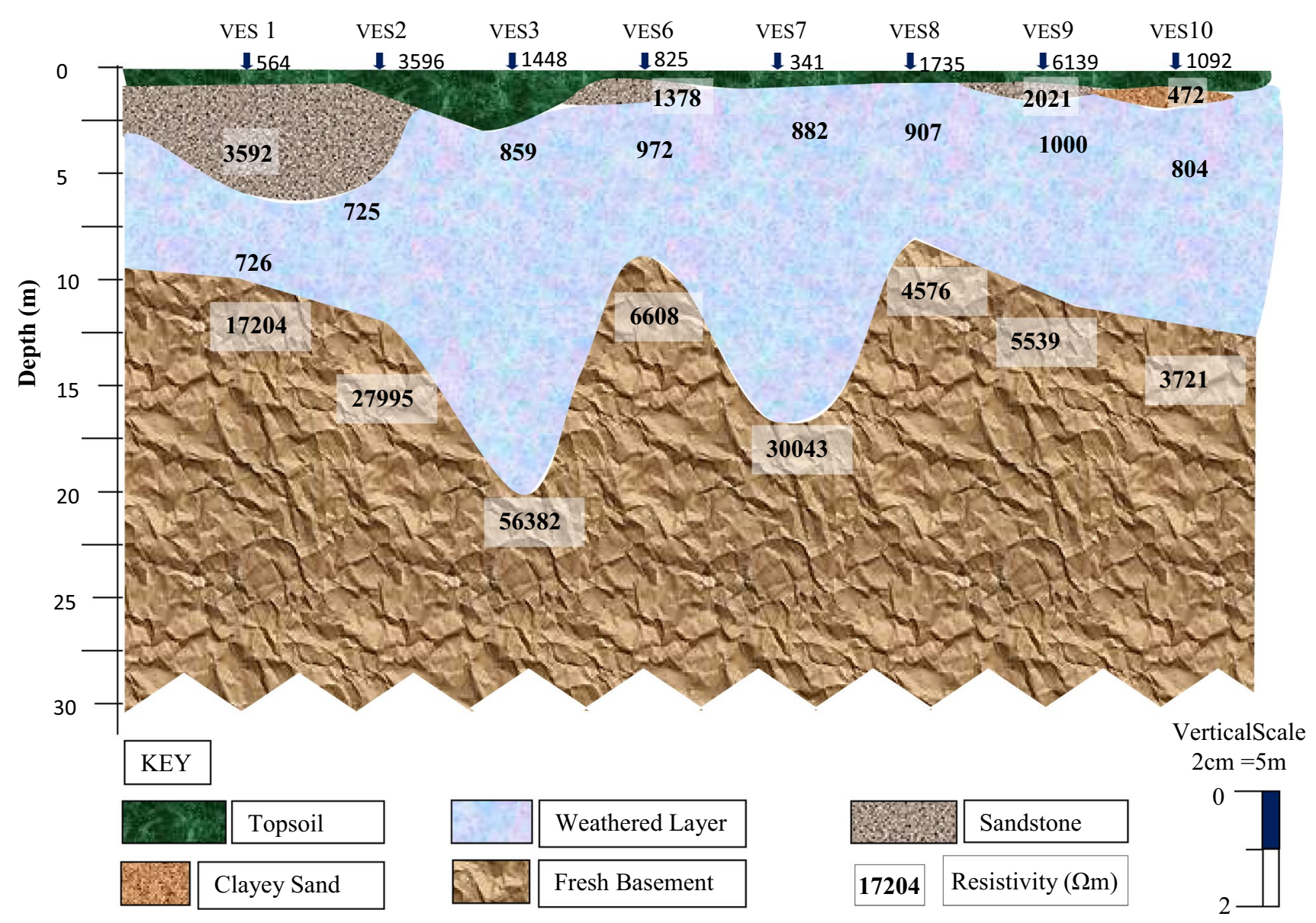

Fig. 20 Layer model interpretation for VES 10

Table 3 Modified longitudinal conductance/protective capacity rating (Oladapo et al. 2004)

\begin{tabular}{ll}
\hline Longitudinal unit conductance (mho) & $\begin{array}{l}\text { Protective } \\
\text { capacity } \\
\text { rating }\end{array}$ \\
\hline$>10$ & Excellent \\
$5-10$ & Very Good \\
$0.7-4.6$ & Good \\
$0.2-0.69$ & Moderate \\
$0.1-0.19$ & Weak \\
$<0.1$ & Poor \\
\hline
\end{tabular}

composed of 3 to 4 geoelectric layers: sandy topsoil, sandstone, weathered layer and fresh basement. VES1, VES 2, VES 6, VES 9 and VES 10 revealed four layers, while VES 3 , VES 4, VES 7 and VES 8 revealed three layers. VES 5 , on the other hand, revealed 5 layers with the weathered layer found in between two sandstone layers. The resistivity range of the topsoil was 341-3596 $\Omega \mathrm{m}$ with thickness ranging from 0.5 to $1.6 \mathrm{~m}$. The resistivity of the sandstone is considerably high, ranging from 1378 to $4333 \Omega \mathrm{m}$ with thickness ranging from 0.8 to $25.4 \mathrm{~m}$. The weathered layer had a resistivity range of 635-1000 $\Omega \mathrm{m}$ with thickness ranging from 2.2 to $19.8 \mathrm{~m}$. The fresh basement has resistivity range of $3721-56,382 \Omega \mathrm{m}$ which extends to infinity. The highly impervious sandy overburden is characterized by relatively low longitudinal conductance, and it offers a weak protection to the underlying aquifer. The protective capacity inferred from the study area is poor as the values of the longitudinal unit conductance range from 0.010 to 0.024 mhos. The geophysical investigation for groundwater potential in the study area with the integration of VLFEM and VES methods revealed a thin and shallow weathered layer that has an average depth to bedrock of $12 \mathrm{~m}$. Generally, the investigation inferred a low groundwater yield with poor protective capacity of sandy overburden. Manual well digging that is targeted on a suspected aquifer at a peak of dry season is advised to economically manage the quest for groundwater exploration in the area. The application of other verifiable geophysical techniques like well logging is, however, recommended for further studies. 
Table 4 Geoelectric properties and Dar-Zarrouk parameters

\begin{tabular}{|c|c|c|c|c|c|}
\hline VES No & Layers & Resistivity $(\Omega \mathrm{m})$ & Thickness (m) & $\begin{array}{l}\text { Longitudinal Unit con- } \\
\text { ductance } S=h / \rho\left(\Omega^{-1}\right)\end{array}$ & $\begin{array}{l}\text { Longitudinal } \\
\text { conductance } \sum S \\
\text { (mhos) }\end{array}$ \\
\hline \multirow[t]{4}{*}{1} & 1 & 564 & 0.51 & 0.0009 & 0.0135 \\
\hline & 2 & 3592 & 0.75 & 0.0002 & \\
\hline & 3 & 726 & 9.02 & 0.0124 & \\
\hline & 4 & 17,204 & - & & \\
\hline \multirow[t]{4}{*}{2} & 1 & 3596 & 0.51 & 0.0001 & 0.0205 \\
\hline & 2 & 1406 & 5.8 & 0.0126 & \\
\hline & 3 & 725 & 5.7 & 0.0078 & \\
\hline & 4 & 27,995 & - & & \\
\hline \multirow[t]{3}{*}{3} & 1 & 1444 & 1.61 & 0.0011 & 0.0241 \\
\hline & 2 & 860 & 19.8 & 0.0230 & \\
\hline & 3 & 560,363 & - & & \\
\hline \multirow[t]{3}{*}{4} & 1 & 1179 & 0.71 & 0.0006 & 0.0150 \\
\hline & 2 & 1753 & 25.4 & 0.0145 & \\
\hline & 3 & 10,285 & - & & \\
\hline \multirow[t]{5}{*}{5} & 1 & 1241 & 0.5 & 0.0004 & 0.0175 \\
\hline & 2 & 4333 & 0.84 & 0.0002 & \\
\hline & 3 & 635 & 2.23 & 0.0035 & \\
\hline & 4 & 4829 & 64.9 & 0.0134 & \\
\hline & 5 & 12,679 & - & & \\
\hline \multirow[t]{4}{*}{6} & 1 & 825 & 0.5 & 0.0006 & 0.0098 \\
\hline & 2 & 1378 & 0.836 & 0.0006 & \\
\hline & 3 & 972 & 8.4 & 0.0086 & \\
\hline & 4 & 6608 & - & & \\
\hline \multirow[t]{3}{*}{7} & 1 & 341 & 0.56 & 0.0016 & 0.0166 \\
\hline & 2 & 882 & 13.2 & 0.0150 & \\
\hline & 3 & 30,043 & - & & \\
\hline \multirow[t]{3}{*}{8} & 1 & 1735 & 0.5 & 0.0003 & 0.0102 \\
\hline & 2 & 907 & 9.04 & 0.0100 & \\
\hline & 3 & 4576 & - & & \\
\hline \multirow[t]{4}{*}{9} & 1 & 6139 & 0.5 & 0.0001 & 0.0107 \\
\hline & 2 & 2021 & 1.7 & 0.0008 & \\
\hline & 3 & 1000 & 9.8 & 0.0098 & \\
\hline & 4 & 5539 & - & & \\
\hline \multirow[t]{4}{*}{10} & 1 & 1092 & 0.5 & 0.0005 & 0.0194 \\
\hline & 2 & 472 & 1.94 & 0.0041 & \\
\hline & 3 & 804 & 12 & 0.0149 & \\
\hline & 4 & 3721 & - & & \\
\hline
\end{tabular}

Authors' contributions All authors contribute to the study conception and design. Material preparation, data collection and analysis were performed by all the authors.

Funding No fund was received for conducting this study.

\section{Declarations}

Conflict of interest The authors declare that they have no conflict of interest in this research work. 
Open Access This article is licensed under a Creative Commons Attribution 4.0 International License, which permits use, sharing, adaptation, distribution and reproduction in any medium or format, as long as you give appropriate credit to the original author(s) and the source, provide a link to the Creative Commons licence, and indicate if changes were made. The images or other third party material in this article are included in the article's Creative Commons licence, unless indicated otherwise in a credit line to the material. If material is not included in the article's Creative Commons licence and your intended use is not permitted by statutory regulation or exceeds the permitted use, you will need to obtain permission directly from the copyright holder. To view a copy of this licence, visit http://creativecommons.org/licenses/by/4.0/.

\section{References}

Adelusi AO, Ayuk MA, John SK (2014) VLF-EM and VES: an application to groundwater exploration in a Precambrian basement terrain SW Nigeria. Ann Geophys 57(1):S0184. https://doi.org/ 10.4401/ag-6291

Adeniji AE, Obiora DN, Omonona OV, Ayuba R (2013) Geoelectrical evaluation of groundwater potentials of Bwari basement area, Central Nigeria. Int J Phys Sci 8(25):1350-1361

Afolayan JF, Olorunfemi MO, Afolabi A (2004) Geoelectric/ electromagnetic VLF survey for groundwater development in a basement terrain - a case study. IFE J Sci 6(1):74-78. https://doi. org/10.4314/ijs.v6i1.32126

Agagu OK (1985) A geological guide to bituminous sediments in Southwestern Nigeria. Unpublished Report, Department of Geology, University of Ibadan

Ahamefula U, Benard IO, Anthony UO (2012) Estimation of aquifer transmissivity using dar zarrouk parameters derived from surface resistivity measurements: a case history from parts of Enugu Town (Nigeria). J Water Resour Protection 4:993-1000

Akintayo OO, Toyin OO, Olorunyomi JA (2014) Determination of location and depth of mineral rocks at Olode Village in Ibadan, Oyo State, Nigeria, Using Geophysical Methods. Int J Geophys. https://doi.org/10.1155/2014/306862

Ako BD (1979) Geophysical prospecting for groundwater in parts of south-western Nigeria. Unpublished PhD thesis. Department of Geology, University of Ife, Ile-Ife, Nigeria p 371

Al-Garni MA (2009) Geophysical investigations for groundwater in a complex subsurface terrain Wadi Fatima, KSA: a case study. Jordan J Civ Eng 3(2):118-136

Ariyo S, Adeyemi G (2012) Geo-electrical characterization of aquifers in the basement complex/ sedimentary transition zone Southwestern Nigeria. Int J Adv Sci Res Technol 2:1

Ariyo SO, Adeyemi GO (2013) Significant of geology and geophysical investigations in groundwater prospecting. a case study from hard rock terrain of Southwestern Nigeria. Glob J Human-Soc Sci Res 13(2) Version 1.0. ISSN 2249-460X. Available at: https://socia 1scienceresearch.org/index.php/GJHSS/ /view/544

Badmus BS, Olatinsu OB (2010) Aquifer Characteristics and groundwater recharge pattern in a typical Basement Complex, Southwestern Nigeria. African J Environ Sci Technol 4(6):328-342

Badmus BS, Olatinsu OB (2012) Geophysical characterization of basement rocks and groundwater potentials using electrical sounding data from Odeda quarry site, South-western, Nigeria. Asian J Earth Sci 5:79-87

Benson KB, Payne KL, Stubben MA (1997) Mapping groundwater contamination using dc resistivity and VLF geophysical methods - a case study. Geophysics 62(1):80-86

Delleur JW (2006) The handbook of groundwater engineering. CRC Press LLC, ISBN, p 9781420006001
Farquharson F, Bullock A (1992) The hydrology of basement complex regions of africa with particular reference to southern Africa. In: Wright E, Burgess W (eds) Hydrogeology of crystalline basement aquifers in Africa, vol 66. Geological Society Special Publication, London, pp 59-76

Falade AO, Amigun JO, Kafisanwo OO (2019) Application of electrical resistivity and very low frequency electromagnetic induction methods in groundwater investigation in ilara-mokin, Akure Southwestern Nigeria. Environ Earth Sci Res J 6(3):125-135

Farquharson F, Bullock A (1992) The hydrology of basement complex regions of Africa with particular reference to Southern Africa. In: Wright E, Burgess W (eds) Hydrogeology of Crystalline Basement Aquifers in Africa, Geological Society Special Publication London, vol 66. pp 59-76

Hassan L, Abdellatif M, Moumtaz R (2017) Modeling of transient two dimensional flow in saturated-unsaturated porous media. Eur Sci J 13(12):1857-7881

Henderson RJ (1992) Urban geophysics - a review. Explor Geophys 32:531-542

Isaac A (2014) The use of Dar-Zarrouk parameters in evaluating groundwater potential of ga south municipality. University Of Mines And Technology Tarkwa, Ghana

James W (2009) New views of the Earth's interior. Astron Geophys 50(3):3.34-3.37

Janvier DK, Noël D, Danwe R, Philippe N, Abdouramani D (2015) A review of geophysical methods for geothermal exploration. Renew Sustain Energy Rev 44:87-95

Kamil E (2008) A comparative overview of geophysical methods. Report No. 488 geodetic science and surveying. The Ohio State University Columbus, Ohio 43210

Khalil MA, Monteiro Santos FA, Moustafa SM, Saad UM (2009) Mapping water seepage from Lake Nasser, Egypt, using the VLF-EM method: a case study. J Geophy 6:101-110

Loke MH (2000) Electrical imaging surveys for environment and engineering studies; a practical guide to $2 \mathrm{D}$ and $3 \mathrm{D}$ survey

Lukuman A, Sikiru AA, Kasim AA, Olusola AA, Olukole AA (2015) Geophysical investigation of subsurface water of Erunmu and its Environs, Southwestern Nigeria using electrical resistivity method. J Appl Sci 15:741-751

McNeill JD, Labson VF (1991) Geological mapping using VLF Radiofields. In: Nabighian MN (ed) Geotechnical and environmental geophysics, vol 1. Review and Tutorial. Society of Exploration Geophysicists, Tulsa, pp 191-218

Mosuro G, Bayewu O, Oloruntola M (2011) Geophysical investigation for groundwater exploration in Kobape via Abeokuta SW, Nigeria, https://doi.org/10.13140/2.1.4183.1686

Ndatuwong, Lazarus, Yadav G (2013) Analysis and interpretation of inphase component of VLF-EM data using hilbert transform and the amplitude of analytical signal. J Environ Earth Sci 3(11):11-24

Nimmo JR (2005) Unsaturated zone flow processes. In: Anderson MG, Bear J (eds) Encyclopedia of hydrological sciences: part 13-Groundwater: Chichester, vol 4. Wiley, UK, pp 2299-2322

Nuraddeen U, Khiruddin A, Mohd N (2019) Investigating the performance of combined resistivity model using different electrode arrays configuration. Arab J Geosci 12(4): 1

Odipe OE, Ogunleye RA, Sulaiman M, Abubakar S, Olorunfemi MO (2018) Integrated geophysical and hydro-chemical investigations of impact of the ijemikin waste dump site in Akure, Southwestern Nigeria, on groundwater quality. J Health Pollut 8:18

Oladapo MI, Mohammed MZ, Adeoye OO, Adetola BA (2004) Geoelectrical investigation of the Ondo State Housing Corporation Estate, Ijapo Akure, Southwestern Nigeria. J Min Geol 40(1):41-48

Olafisoye ER, Sunmonu LA, Ojoawo A, Adagunodo TA, Oladejo OP (2012) Application of very low frequency electromagnetic and hydrophysicochemical methods in the investigation of

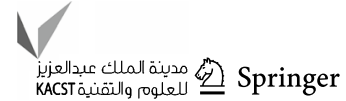


groundwater contamination at Aarada waste disposal site Ogbomoso, Southwestern Nigeria. Aust J Basic Appl Sci 6:401-409

Oladele S, Odubote O (2017) Aquifer mapping and characterization in the complex transition zone of Ijebu Ode, SouthwesternNigeria. Forum Geografic XVI(1):49-58. https://doi.org/10.5775/ fg.2017.112.i

Olayanju GM (2011) Very low frequency - electromagnetic (VLF-EM) and Offset Wenner resistivity survey of spring sources for groundwater development. Int J Water Res Environ Eng 3(13):324-340

Olorunfemi MO, Dan-Hassan MA (1999) Hydrogeophysical investigation of a Basement terrain in the north-central part of Kaduna state, Nigeria. J Min Geol 35(2):189-206

Osinowo OO, Olayinka AI (2012) Very low frequency electromagnetic (VLF-EM) and electrical resistivity (ER) investigation for groundwater potential evaluation in a complex geological terrain around the Ijebu-Ode transition zone, southwestern Nigeria. J Geophy Eng 9(4):374-396. https://doi.org/10.1088/1742-2132/9/4/374

Palacky GJ, Ritsema IL, de Jong SJ (1981) Electromagnetic prospection for groundwater in Precambrian terrains in the Republic of Upper Volta. Geophys Prospect 29:932-955

Pirttijärvi M (2004) Karous-Hjelt and Fraser filtering of VLF measurements Version 1 1a

Ram RM, Rao KS (2018) Efficacy of integrated geophysical techniques in delineating groundwater potential zones in the Deccan Basalt region of Maharashtra. J Ind Geophys Union 22(3):257-264

Reynolds JM (1997) An introduction to applied and environment geophysics. John Wiley \& Sons, New Jersey, USA
Selby MJ (1985) Earth's changing surface. Clarendon Press, Oxford. p 607

Srigutomo W, Harja A, Sutarno D, Kagiyama T (2005) VLF data analysis through transformation into resistivity value: application to synthetic and field data Indonesia. J Phys 16(4):127-136

Sriramulu G, Ramadass G, Kumar DV (2017) Very Low frequency electromagnetic, magnetic and radiometric surveys for lamproite investigation in Vattikod area of Nalgonda District, Telangana State, India. Pelag Res Libr 1:138-145

Sundararajan N, Ramesh BV, Shiva PN, Srinivas Y (2006) VLFPROS - a matlab code for processing of VLF-EM data. Comput Geosci 32:1806-1813

Sundararajan N, Nandakumar G, Narsimha M, Srinivas Y (2007) VES and VLF - an application to groundwater exploration Khammam, India. The Lead Edge 26(6):708-716

Telford WM, Geldart LP, Sheriff RE, (1990) Applied Geophysics, 2nd ed., Cambridge University Press, $770 \mathrm{p}$

Usman MA, Ibrahim AA (2017) Petrography and geochemistry of rocks of northern part of Wonaka Schist Belt Northwestern Nigeria. Niger J Basic Appl Sci 25(2):87-99

WWDR (2015) Water for a sustainable world, facts and figures, The United Nations World Water Development Report

Yusuf TU (2016) Overview of effective geophysical methods used in the study of environmental pollutions by waste dumpsites. An Int Multi-Discip J Ethiop 10(2):123-143 